\title{
Lactobacillus manihotivorans sp. nov., a new starch-hydrolysing lactic acid bacterium isolated during cassava sour starch fermentation
}

\author{
J. Morlon-Guyot, ${ }^{1}$ J. P. Guyot, ${ }^{1}$ B. Pot, ${ }^{2}$ I. Jacobe de Haut ${ }^{1}$ \\ and M. Raimbault ${ }^{1}$
}

\author{
Author for correspondence: J. Morlon-Guyot. Tel: +334674162 78. Fax: +33467416283. \\ e-mail: morlon $\propto$ mpl.orstom.fr
}

\footnotetext{
1 Laboratoire de Biotechnologie Microbienne Tropicale, Institut Francais de Recherche scientifique pour le développement en Coopération (ORSTOM), BP 5045,34032 Montpellier cedex 1, France

2 BCCM $/$ /LMG Laboratorium voor Microbiologie, Universiteit Gent, B-9000 Gent, Belgium
}

\begin{abstract}
Two Lactobacillus strains were isolated from sour cassava starch fermentation. The cells were Gram-positive, catalase-negative, non-spore-forming, nonmotile rods. They produced only $L(+)$ lactate and were homofermentative. Growth occurred at pH values of 5.0-7.0 and optimum growth occurred at pH 6.0. Growth was positive at 15 and $45{ }^{\circ} \mathrm{C}$. The DNA G+C content was 48.4 $\pm 0.2 \mathrm{~mol} \%$. Sequence analysis of the 16S rRNA gene revealed that strains OND $32^{\top}$ and YAM 1 clustered with, but were separate from Lactobacillus caseirelated taxa. Protein pattern and sequence analyses of the 165 rRNA gene confirmed that the two new isolates represent a new Lactobacillus species, for which the name Lactobacillus manihotivorans is proposed; strain OND $32^{\top}$ is the type strain of this species.
\end{abstract}

Keywords: lactic acid bacteria, Lactobacillus manihotivorans sp. nov., amylase, cassava, sour starch

\section{INTRODUCTION}

To date, only a few amylolytic lactic acid bacteria (ALAB) have been isolated, such as Lactobacillus amylophilus and Lactobacillus amylovorus from swine and cattle waste-corn fermentations, respectively, in the USA (Nakamura, 1981; Nakamura \& Crowell, 1979), Lactobacillus plantarum A6 from retted cassava roots in Congo (Giraud et al., 1991), Lactobacillus strains LEM 220, 207 and 202 from chicken crop in France (Champ et al., 1983), Leuconostoc strains from fish silage in Sweden (Lindgren \& Refai, 1984), and $L$. plantarum from fermented fish and rice food in Japan (Olympia et al., 1995). Among the most representative species, $L$. amylovorus had higher amylase activity than L. amylophilus (Pompeyo et al., 1993) and both species were studied for their ability to produce lactic acid from starch (Mercier et al., 1992; Yumoto \& Ikeda, 1995; Zhang \& Cheyran, 1991). Furthermore, it was shown that $L$. plantarum A6 was able to ferment

Abbreviations: ALAB, amylolytic lactic acid bacteria; RDP, Ribosomal Database Project.

The GenBank accession numbers for the 16S rRNA sequences of strains OND $32^{\top}$ and YAM 1 reported in this paper are AF000162 and AF000163, respectively. raw starch (Giraud et al., 1991). The fact that amylolytic Lactobacillus strains were most often isolated from food-related ecosystems is congruent with a recent survey of Damelin et al. (1995), who reported that these bacteria constituted up to $65 \%$ of the isolates from different types of foods.

Cassava sour starch is a sun-dried fermented food product in Latin America with an unusual breadmaking capacity. It is produced mainly in Colombia (Dufour et al., 1995) and in Brazil (Chuzel et al., 1995) where it is named 'almidon agrio' and 'polvilho azedo', respectively. Production of cassava sour starch involves lactic acid fermentation and a decrease in $\mathrm{pH}$ to 3.5 (Dufour et al., 1995). Nevertheless, the quality of sour starch is quite variable and this affects the breadmaking capacity. Direct use of starch with selected starters could be utilized to better control the process.

Tropical fermented foods made from starch-containing substrates like cassava or corn are potential sources of new strains of ALAB which produce $\mathrm{L}(+)$ lactic acid. These strains would be more acceptable for human food applications than those isolated from waste products or animal guts. Furthermore, the systematic isolation and characterization of ALAB from different food-related eco- 
systems would help in the future to establish the ecological significance of this particular group of bacteria. This work reports the isolation of a new ALAB species from sour starch production in Colombia for which the name Lactobacillus manihotivorans is proposed.

\section{METHODS}

Origin of the isolates. Strains OND $32^{T}$ and YAM 1 were isolated during sour starch production in Colombia on agar plates containing MRS medium with soluble starch (Prolabo) as substrate using the same procedure described for L. plantarum A6 (Giraud et al., 1991). Strains OND 32" and YAM 1 were selected for their ability to degrade soluble starch. All strains were stored in $20 \%$ glycerol at $-80^{\circ} \mathrm{C}$. The two isolates obtained (strains OND $32^{\mathrm{T}}$ and YAM 1) were deposited in the Belgian Coordinated Collections of Microorganisms/Laboratorium voor Microbiologie Universiteit Gent (BCCM/LMG) culture collection as strains LMG $18010^{\mathrm{T}}$ and LMG 18011 , respectively.

Culture conditions. MRS medium (with glucose or soluble starch as substrate) was routinely used for general cultivation of bacteria (De Man et al., 1960). The ability to grow under anaerobic or aerobic conditions was determined in Hungate tubes containing MRS broth (Difco), without shaking. For anaerobic growth, the medium was prepared under strict anaerobic conditions (Balch et al., 1979) with $\mathrm{O}_{2}$-free $\mathrm{N}_{2}$ in the headspace. The temperature range for growth was determined with thermostatically controlled water baths, and the $\mathrm{pH}$ range for growth was determined at $30^{\circ} \mathrm{C}$ in 21 fermenters (Biolafitte) with $\mathrm{pH}$ control.

The API 50 CHL system (bioMérieux) was used to determine acid production from carbohydrates. Reproducibility was verified by repeated analysis using cultures grown on MRS agar and subcultured in liquid MRS medium prior to inoculation.

Analytical techniques. Cell density of culture was measured at $600 \mathrm{~nm}$ with a Spectronic 401 (Milton Roy) following the procedure of Koch (1981). Catalase activity was tested as described previously (Combet-Blanc et al., 1995). Lactic acid configuration and concentration were determined using commercial enzymic test combinations (Boehringer Mannheim). The metabolic products in the supernatant were determined by HPLC using an Aminex HPX $87 \mathrm{H}$ column (Bio-Rad) with $6 \mathrm{mM} \mathrm{H}_{2} \mathrm{SO}_{4}$ at a flow rate of $0.8 \mathrm{ml} \mathrm{min}^{-1}$ and $65^{\circ} \mathrm{C}$ with refractive index detection. Extracellular $\alpha$ amylase activity was assayed in the supernatant of centrifuged cultures by measurement of the iodine-complexing ability of starch at pH 5.5 and $55^{\circ} \mathrm{C}$ as previously described (Giraud et al., 1994). All tests were done in duplicate.

Morphological characteristics. Cell morphology was observed by phase-contrast microscopy. Gram staining was studied using a Gram-colour coloration set (Merck) and by the $\mathrm{KOH}$ method of Gregersen (1978).

DNA base composition. The $\mathrm{G}+\mathrm{C}$ content of the DNA was determined at the Deutsche Sammlung von Mikroorganism und Zellkulturen, Braunschweig, Germany. After disruption with a French pressure cell, the DNA was isolated and purified by chromatography on hydroxyapatite. The $\mathrm{G}+\mathrm{C}$ content was determined by HPLC as described by Meshbah et al. (1989); non-methylated lambda DNA (Sigma) was used as the internal standard.
SDSPAGE. Whole-cell protein extracts were prepared and SDS-PAGE was performed as described previously (Pot et al., 1994a). Registration of the protein electrophoretic patterns, normalization of the densitometric traces, grouping of strains with the Pearson product-moment correlation coefficient (Pearson \& Lipman, 1988), and an unweighted pair group cluster analysis using average linkage were performed using the techniques described by Pot $e t$ al. (1994a) with the GELCOMPAR software package (version 4.0) (Vauterin \& Vauterin, 1992). The protein profile of strain OND $32^{\mathrm{T}}$ and YAM 1 was compared with a database consisting of normalized protein fingerprints derived from reference strains belonging to almost all previously described species of lactic acid bacteria (Pot \& Janssens, 1993).

Purification of genomic DNA and standard electrophoresis. Genomic DNA was prepared in agarose blocks, similarly to preparation of DNA samples for pulsed field gel electrophoresis. An overnight culture of strains OND $32^{\mathrm{T}}$ and YAM 1 was diluted $\left(10^{-1}\right)$ in fresh MRS broth and grown at $30^{\circ} \mathrm{C}$ for $4 \mathrm{~h}$. The cells were harvested by centrifugation (10 min, 5000 r.p.m.), washed twice in TS buffer $(50 \mathrm{mM}$ Tris $/ \mathrm{HCl}, \mathrm{pH} 7 \cdot 5,25 \%$ saccharose, w/w). The cells were then suspended in TS buffer to an $A_{600}$ value of about 3 . The cell suspension $(1 \mathrm{ml})$ was treated with lysozyme $(100 \mathrm{mg}$ $\mathrm{ml}^{-1}$ ) for $1 \mathrm{~h}$ at $37^{\circ} \mathrm{C}$. The protoplasts thus obtained were harvested by centrifugation $(10 \mathrm{~min}, 5000$ r.p.m.), resuspended in $500 \mu \mathrm{l} \mathrm{SE}$ buffer $(75 \mathrm{mM} \mathrm{NaCl}, 25 \mathrm{mM}$ EDTA) and incubated for $1 \mathrm{~h}$ at $37^{\circ} \mathrm{C}$. The agarose blocks were prepared and digested with EcoRI endonuclease according to the method of McClelland (1987). Standard electrophoresis of the DNA samples was performed in a large electrophoresis cell $(30 \times 20 \mathrm{~cm})$ with $1 \%$ agarose gel $(\mathrm{w} / \mathrm{v})$, in TAE buffer ( $40 \mathrm{mM}$ Tris, $40 \mathrm{mM}$ acetate, $2.0 \mathrm{mM}$ EDTA, $\mathrm{pH} 8$ ) at $4 \mathrm{~V} \mathrm{~cm}^{-1}$ and $10^{\circ} \mathrm{C}$ for $15 \mathrm{~h}$.

$16 \mathrm{~S}$ rRNA gene sequencing. The almost complete $16 \mathrm{~S}$ rRNA gene was amplified by PCR by using domain Bacteriaspecific primers $27 \mathrm{f}$ and $1425 \mathrm{r}$ (Lane, 1991). PCR reactions were done in a final volume of $100 \mu$ containing: $0 \cdot 1-0 \cdot 5 \mu \mathrm{g}$ DNA, deoxyribonucleoside triphosphate $(200 \mu \mathrm{M}$ each), primers $\left(0.8 \mu \mathrm{M}\right.$ each), $\mathrm{MgCl}_{2}(1.5 \mathrm{mM}), 1 \mathrm{U}$ Taq DNA polymerase (Promega), and the buffer supplied with the enzyme. The amplification conditions were as follows : initial denaturation at $94{ }^{\circ} \mathrm{C}$ for $5 \mathrm{~min} ; 30$ cycles of denaturation for $30 \mathrm{~s}$ at $94{ }^{\circ} \mathrm{C}$; annealing for $30 \mathrm{~s}$ at $55^{\circ} \mathrm{C}$; and elongation at $72{ }^{\circ} \mathrm{C}$ for $7 \mathrm{~min}$. The amplified fragments were purified by a Wizard procedure and ligated into vector pGEM-T (Promega).

Both strands of the inserts of the clones were sequenced by the dideoxy chain-termination method (Sanger et al., 1977) with the ABI PRISM Dye Terminator kit (Perkin Elmer). Sequence products were loaded and analysed on a 373 DNA sequencer (Applied Biosystems).

Phylogenetic analysis of the sequence data. Phylogenetic analyses were performed using data from the Ribosomal Database Project (RDP; Maidak et al., 1996), the CLUSTAL w multi-alignment program (Thomson et al., 1994) and PHYLIP (Phylogeny Inference Package version 3.5c; Felsenstein, 1993).

To determine the closest known relative of the two new 16S rDNA sequences, preliminary searches were performed in public data libraries (GenBank and RDP) with the FASTA (Devereux et al., 1984) and RDP programs (Maidak et al., 1996). Then, the new sequences were aligned with 24 related sequences using the CLUSTAL w program (Thomson et al., 
1994). Positions of sequence alignment uncertainty were omitted from the sequence analyses. A distance matrix was obtained by using the DNADIST program (Felsenstein, 1993) and the method of Jukes \& Cantor (1969). The stability of the groups was determined by performing bootstrap analysis with 100 bootstrapped data sets and with the programs DNABOOT, DNAPARS, DNAML, DNADIST, NEIGHBOR and CONSENSE (Felsenstein, 1993).

\section{RESULTS}

\section{Colony and cell morphology}

Colonies of strains OND $32^{\mathrm{T}}$ and YAM 1 on MRS agar were white, convex and opaque with smooth edges. Clear zones of starch hydrolysis were observed on exposure of colonies grown on MRS agar containing starch $\left(15 \mathrm{~g} \mathrm{l}^{-1}\right)$ to iodine vapour.

Cells of strains OND $32^{\mathrm{T}}$ and YAM 1 were non-sporeforming, non-motile rods that occurred in short, straight to curled, small crisped chains. The Gram stain reaction was positive.

\section{DNA base composition}

The mean $\mathrm{G}+\mathrm{C}$ content of strain OND $32^{\mathrm{T}}$ DNA, based on three determinations, was $48 \cdot 4 \pm 0 \cdot 2 \mathrm{~mol} \%$.

\section{Growth conditions and metabolic properties}

Strains OND $32^{\mathrm{T}}$ and YAM 1 were catalase-negative. Both strains grew well in liquid or solid MRS media in the presence of air and also under strict anaerobic conditions. Strains OND $32^{\mathrm{T}}$ and YAM 1 produced only $\mathrm{L}(+)$ lactic acid. In MRS medium containing starch as the energy source at $\mathrm{pH} 6.0$ and $30^{\circ} \mathrm{C}$, the specific growth rate of strain OND $32^{\mathrm{T}}$ was $0 \cdot 31 \pm 0.02 \mathrm{~h}^{-1}$. Strain OND $32^{\mathrm{T}}$ required complex nitrogen sources for growth, such as meat extract and pancreatic peptone. For strain OND $32^{\mathrm{T}}$, growth occurred at 15 and $45^{\circ} \mathrm{C}$ and was optimal at approximately $30{ }^{\circ} \mathrm{C}$. The strain grew at $\mathrm{pH}$ values of $5 \cdot 0-7 \cdot 0$, the optimum being 6.0. Strain OND $32^{\mathrm{T}}$ was able to grow at $\mathrm{NaCl}$ concentrations of $20-65 \mathrm{~g}^{-1}$ and did not grow at $100 \mathrm{~g} \mathrm{NaCl}^{-1}$.

Amylolytic activity in strain OND $32^{\mathrm{T}}$ was extracellular, whereas strain YAM 1 had a cell-linked amylase activity and did not produce extracellular amylolytic enzyme.

\section{Fermentation of sugars by strain OND $32^{\top}$ and YAM 1}

The following sugars were fermented within $24 \mathrm{~h}$ : galactose, D-glucose, D-fructose, D-mannose, methyl $\alpha$-D-glucoside, $N$-acetylglucosamine, amygdalin, arbutin, aesculin, salicin, cellobiose, maltose, lactose, melibiose, sucrose, trehalose, D-raffinose, starch, glycogen, $\beta$-gentobiose and $\mathrm{D}$-turanose.

Glycerol, erythritol, D-arabinose, D-ribose, D-xylose, L-xylose, adonitol, methyl $\beta$-xyloside, L-sorbose, rhamnose, dulcitol, inositol, mannitol, sorbitol, methyl $\alpha$-Dmannoside, inulin, melezitose, xylitol, D-lyxose, D-

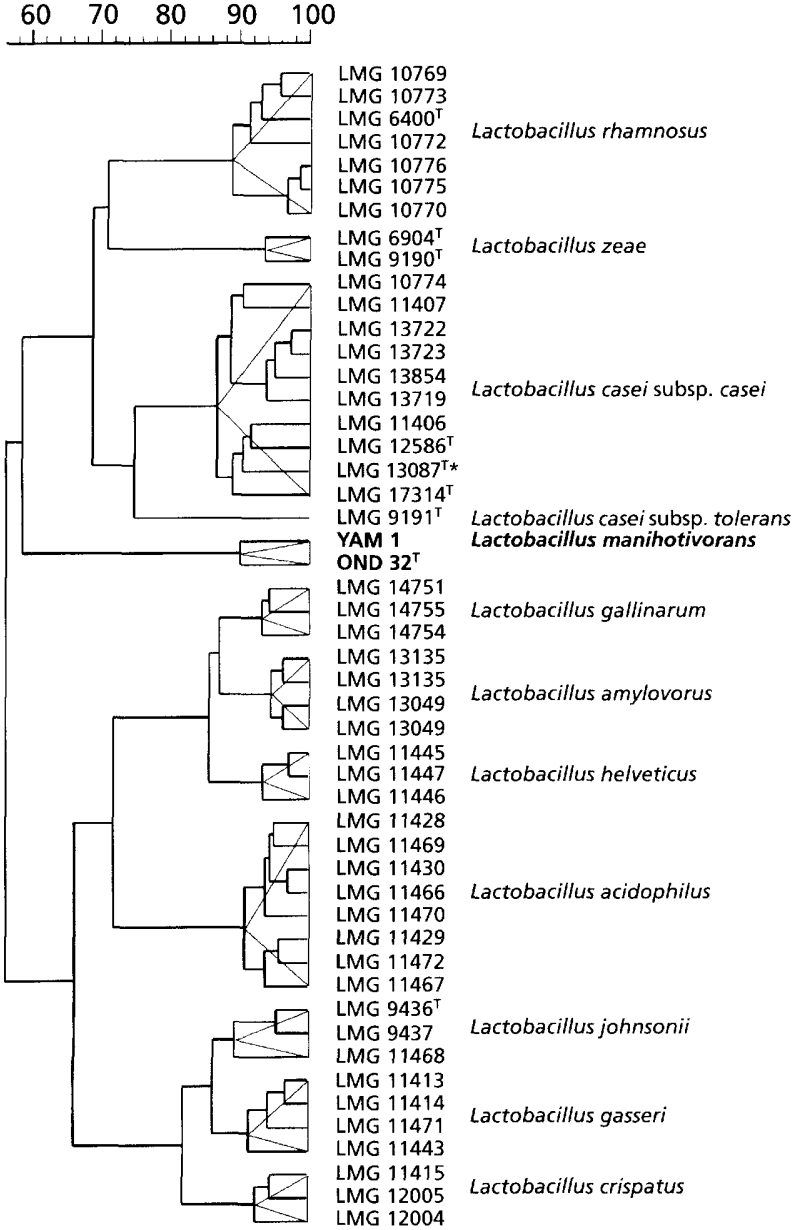

Fig. 1. Dendrogram derived from SDS-PAGE protein pattern analysis. The mean correlation coefficient is expressed as a percentage $(r \times 100)$ and represented as a dendrogram calculated by the unweighted mean pair grouping method, for a number of relevant Lactobacillus species. Species are delineated by triangles. Points $10-325$ of the 400 point traces were used to calculate similarities between the individual pairs of traces. LMG, BCCM/LMG culture collection, University of Gent, Gent, Belgium; *, type strain of $L$. paracasei as described by Collins et al. (1989).

tagatose, D-fucose, L-fucose, D-arabitol, L-arabitol, gluconate, 2-ketogluconate and 5-ketogluconate were not fermented.

\section{SDS-PAGE}

Both isolates were included in an identification procedure using SDS-PAGE of whole-cell proteins. The protein patterns of both strains were compared to a database containing the SDS-PAGE fingerprints of almost all known species of lactic acid bacteria (Pot \& Janssens, 1993; Pot et al., 1994a). Numerical analysis of the SDS-PAGE protein patterns, represented as a dendrogram and including representative strains of some phenotypically and phylogenetically relevant species, is presented in Fig. 1. The dendrogram obtained clearly shows the separate species status of 
Table 1. Similarity values (\%) for the $16 \mathrm{~S}$ rRNA genes of strains OND $32^{\top}$ and YAM 1, selected lactic acid bacteria and E. coli

Similarity values were determined using Olsen's modification of the method of Jukes \& Cantor (1969) (see Methods). 1, OND $32^{\mathrm{T}}$; 2, YAM 1; 3, Lactobacillus agilis; 4, L. amylophilus; 5, L. amylovorus; 6, Lactobacillus bifermentans; 7, Lactobacillus brevis; 8, Lactobacillus buchneri; 9, L. casei; 10, Lactobacillus coryniformis; 11, L. delbrueckii; 12, Lactobacillus fermentum; 13, Lactobacillus fructivorans; 14 , Lactobacillus hilgardii; 15, L. mali; 16 , Lactobacillus murinus; 17, Lactobacillus pentosus; 18, L. plantarum; 19, L. ruminis; 20, Lactobacillus sakei; 21, L. sharpeae; 22, Lactobacillus vermiforme; 23, Leuconostoc cremoris; 24 . Pediococcus acidilactici; 25, Pediococcus pentosaceus; 26, E. coli.

\begin{tabular}{|c|c|c|c|c|c|c|c|c|c|c|c|c|c|c|c|c|c|c|c|c|c|c|c|c|c|c|}
\hline Species & 1 & 2 & 3 & 4 & 5 & 6 & 7 & 8 & 9 & 10 & 11 & 12 & 13 & 14 & 15 & 16 & 17 & 18 & 19 & 20 & 21 & 22 & 23 & 24 & 25 & 26 \\
\hline 1 & 100 & & & & & & & & & & & & & & & & & & & & & & & & & \\
\hline 2 & 99.4 & 100 & & & & & & & & & & & & & & & & & & & & & & & & \\
\hline 3 & 91.6 & 906 & 100 & & & & & & & & & & & & & & & & & & & & & & & \\
\hline 4 & 90.5 & 900 & 88.7 & 100 & & & & & & & & & & & & & & & & & & & & & & \\
\hline 5 & 89.3 & $89 \cdot 0$ & 87.0 & $90 \cdot 9$ & 100 & & & & & & & & & & & & & & & & & & & & & \\
\hline 6 & 93.4 & $93-1$ & $90 \cdot 3$ & 90.7 & 87.9 & 100 & & & & & & & & & & & & & & & & & & & & \\
\hline 7 & 93.3 & $93 \cdot 1$ & 90.9 & $90 \cdot 6$ & 87.0 & $92 \cdot 0$ & 100 & & & & & & & & & & & & & & & & & & & \\
\hline 8 & 93.5 & $93 \cdot 3$ & 91.4 & $90 \cdot 2$ & 87.7 & 92.6 & $95 \cdot 2$ & 100 & & & & & & & & & & & & & & & & & & \\
\hline 9 & 94.9 & 94.6 & 90.7 & $90 \cdot 2$ & 87.5 & 91.6 & $92 \cdot 1$ & 91.9 & 100 & & & & & & & & & & & & & & & & & \\
\hline 10 & 93.8 & 93.5 & 91.9 & 90.5 & 87.7 & $95 \cdot 3$ & 92.4 & $92 \cdot 3$ & $93 \cdot 2$ & 100 & & & & & & & & & & & & & & & & \\
\hline 11 & $89 \cdot 5$ & $89 \cdot 3$ & 87.4 & 89.6 & $92 \cdot 4$ & 88.8 & 89.1 & 87.6 & 88.6 & 87.9 & 100 & & & & & & & & & & & & & & & \\
\hline 12 & $90 \cdot 7$ & 90.5 & 89.2 & $90 \cdot 3$ & 87.8 & 89.8 & 91.6 & 89.4 & $90 \cdot 1$ & 88.7 & 88.7 & 100 & & & & & & & & & & & & & & \\
\hline 13 & $92 \cdot 6$ & 92.6 & $90 \cdot 0$ & $89 \cdot 0$ & 86.9 & $90 \cdot 9$ & $94 \cdot 5$ & 93.1 & 92.5 & $90 \cdot 3$ & 88.4 & 91.1 & 100 & & & & & & & & & & & & & \\
\hline 14 & $92 \cdot 8$ & 92.5 & $91 \cdot 1$ & $90 \cdot 0$ & 87.3 & 91.9 & 94.8 & $96 \cdot 3$ & 93.6 & 91.7 & 88.2 & $9(0 \cdot 9$ & 94.8 & 100 & & & & & & & & & & & & \\
\hline 15 & $92 \cdot 4$ & 92.3 & 94.4 & 89.8 & 87.3 & 91.7 & $93 \cdot 3$ & 92.9 & 92.7 & 92.7 & 88.0 & $90 \cdot 3$ & 93.5 & $92 \cdot 9$ & 100 & & & & & & & & & & & \\
\hline 16 & 91.4 & 91.5 & 94.3 & 88.7 & $86 \cdot 2$ & $90 \cdot 4$ & $92 \cdot 1$ & 91.1 & $91 \cdot 8$ & 91.1 & $88 \cdot 2$ & 89.8 & $92 \cdot 1$ & $90 \cdot 9$ & 94.5 & 100 & & & & & & & & & & \\
\hline 17 & $93 \cdot 3$ & $93 \cdot 1$ & 91.5 & 89.7 & $85 \cdot 7$ & 92.5 & 94.8 & 91.5 & 92.0 & 91.9 & 87.6 & 90.7 & 93.7 & $92 \cdot 2$ & 92.4 & 88.8 & 100 & & & & & & & & & \\
\hline 18 & $93 \cdot 3$ & $93 \cdot 1$ & 91.5 & 89.7 & $85 \cdot 7$ & 92.5 & 94.8 & 91.5 & 92.0 & 91.9 & 87.6 & 90.7 & 93.7 & $92 \cdot 2$ & $92 \cdot 4$ & 88.8 & 100 & 100 & & & & & & & & \\
\hline 19 & 90.8 & 90.8 & 93.7 & 88.5 & 86.2 & 900 & $92 \cdot 1$ & 91.0 & $90 \cdot 5$ & $90 \cdot 1$ & 87.5 & $89 \cdot 8$ & 91.8 & $90 \cdot 9$ & $93 \cdot 2$ & 91.3 & 92.3 & $92 \cdot 3$ & 100 & & & & & & & \\
\hline 20 & 93.4 & $93 \cdot 1$ & $90 \cdot 3$ & 9000 & 87.2 & 92.2 & $92 \cdot 4$ & 91.5 & 93.6 & 93.5 & 88.2 & $90 \cdot 7$ & 92.7 & 91.7 & $92 \cdot 3$ & $89 \cdot 3$ & 93.1 & $93 \cdot 1$ & $90 \cdot 4$ & 100 & & & & & & \\
\hline 21 & 93.9 & 93.4 & $89 \cdot 0$ & $89 \cdot 4$ & 88.4 & 91.8 & 92.9 & 91.7 & $92 \cdot 3$ & 91.8 & 89.1 & $90 \cdot 6$ & 91.7 & $90 \cdot 6$ & 91.1 & 88.4 & 91.7 & 91.7 & 89.8 & 92.5 & 100 & & & & & \\
\hline 22 & 92.7 & 92.5 & 91.4 & $90 \cdot 2$ & 87.4 & $92 \cdot 1$ & 950 & 96.7 & 93.8 & 91.9 & 88.2 & $90 \cdot 9$ & $94-8$ & 98.5 & 93.7 & 89.6 & 93.7 & 93.7 & $92 \cdot 1$ & 92.7 & 91.3 & 100 & & & & \\
\hline 23 & $86 \cdot 4$ & $86 \cdot 3$ & 85.4 & 84.7 & 83.6 & 86.0 & 85.5 & 84.0 & 85.9 & 85.9 & 84.3 & 85.9 & $84 \cdot 7$ & $84 \cdot 0$ & $85 \cdot 3$ & $83 \cdot 2$ & 85.9 & 85.9 & 84.7 & $86 \cdot 7$ & 86.5 & 83.8 & 100 & & & \\
\hline 24 & 93.3 & $92 \cdot 9$ & 90.5 & $89 \cdot 8$ & 87.2 & 92.0 & $94 \cdot 3$ & 93.1 & $93 \cdot 3$ & 91.7 & 87.8 & 91.9 & $94 \cdot 4$ & 92.5 & $93 \cdot 4$ & 89.6 & $94 \cdot 2$ & $94 \cdot 2$ & 90.9 & 93.5 & $93 \cdot 3$ & 92.7 & $85 \cdot 3$ & 100 & & \\
\hline 25 & 93.2 & $92 \cdot 8$ & $90 \cdot 1$ & $88 \cdot 9$ & $86 \cdot 4$ & $91 \cdot 3$ & $94 \cdot 0$ & $92 \cdot 0$ & $93 \cdot 1$ & 91.0 & 87.4 & 90.9 & $94 \cdot 0$ & 92.1 & $92 \cdot 8$ & $89 \cdot 1$ & 93.9 & 93.9 & 90.9 & 92.5 & 92.2 & $92 \cdot 2$ & $85 \cdot 2$ & 97.3 & 100 & \\
\hline 26 & 77.0 & 76.9 & 75.8 & 7600 & 74.8 & $76 \cdot 6$ & 76.0 & $75 \cdot 5$ & 77.4 & $75 \cdot 6$ & $76 \cdot 5$ & 75.9 & 76.9 & 75.3 & 76.0 & 74.3 & $76 \cdot 9$ & 76.9 & 77.2 & $76 \cdot 2$ & $76 \cdot 2$ & $75 \cdot 1$ & 76.8 & $75 \cdot 7$ & $76 \cdot 3$ & 100 \\
\hline
\end{tabular}

the two strains LMG 18011 (YAM 1) and LMG $18010^{\mathrm{T}}\left(\mathrm{OND} 32^{\mathrm{T}}\right)$. Both strains show a correlation value $(r \times 100)$ of $90.2 \%$ with each other and less than $58 \%$ with the other lactobacilli included in the dendrogram.

Reproducibility of the SDS-PAGE method was estimated by studying duplicate lanes of a single protein extract on one gel ( $97 \%$ reproducibility), on separate gels $(\geqslant 94 \%$; see duplicate samples of the two reference strains of L. amylovorus LMG 13135 and 13049 , Fig. 1) or by comparing duplicate extract preparations applied on different gels ( $\geqslant 93 \%$; see duplicate samples of the independently received subcultures of the type strains of Lactobacillus zeae LMG $6904^{\mathrm{T}}$ and LMG $9190^{\mathrm{T}}$, and Lactobacillus casei subsp. casei LMG $12586^{\mathrm{T}}$ and LMG $17314^{\mathrm{T}}$, Fig. 1). These values are in agreement with those reported previously for other lactic acid bacteria (Pot et al., 1993, 1994b).

\section{Whole-genome restriction fragment analysis}

Whole genomic DNA fingerprinting was used only to distinguish both strains OND $32^{\mathrm{T}}$ and YAM 1 . Digestion of total genomic DNA with EcoRI gave complex DNA patterns which were very reproducible. DNA fingerprints obtained for each strain confirmed the separate species status of strains OND $32^{\mathrm{T}}$ and YAM 1 (data not shown) as suggested by SDS-PAGE analysis.

\section{S rRNA sequence and phylogenetic analysis}

The 16S rDNA fragments from strains OND $32^{\mathrm{T}}$ and YAM 1 were amplified by PCR using the primer pair 27f/1525r defined by Lane (1991). The fragments obtained, corresponding to the almost complete sequence of $16 \mathrm{~S}$ rDNA, were sequenced (1559 bases for OND $32^{\mathrm{T}}$ and 1565 bases for YAM 1). Data searches indicated that OND $32^{\mathrm{T}}$ and YAM 1 were members of the subphylum containing Gram-positive bacteria with DNA $\mathrm{G}+\mathrm{C}$ contents less than $55 \mathrm{~mol} \%$, which included members of the genera Lactobacillus, Pediococcus, Streptococcus and Carnobacterium. Similarity values for a 1390 nucleotide region [positions 10-1400 of the Escherichia coli numbering system (Neef et al., 1990)] of these two new sequences and homologous regions of 24 selected reference strains from major phylogenetic lines within the lactic acid bacteria were determined. A matrix of representative sequence similarities is shown in Table 1. Strains OND $32^{\mathrm{T}}$ and YAM 1 showed a high level of similarity $(99.4 \%)$ and this suggests that both strains belong to the same species. For both strains, the highest level of sequence relatedness was observed with $L$. casei (levels of similarity were approximately 94.7 and $94.3 \%$ with OND $32^{\mathrm{T}}$ and YAM 1, respectively) and with other members of the L. casei / Pediococcus cluster (Collins et al., 1991) (similarities were approximately 90.8 $94 \cdot 7 \%$ ). These data show that OND $32^{\mathrm{T}}$ and YAM 1 
Table 2. $16 \mathrm{~S}$ rRNA sequence similarity values (\%) for strains OND $32^{\top}$, YAM 1 and $L$. casei-related species

Similarity values were determined using Olsen's modification of the method of Jukes \& Cantor (1969).

\begin{tabular}{|c|c|c|c|c|c|c|}
\hline Species & OND $32^{\mathrm{T}}$ & YAM 1 & L. casei & L. paracasei & L. rhamnosus & L. zeae \\
\hline L. manihotivorans OND $32^{\mathrm{T}}$ & 100 & & & & & \\
\hline L. manihotivorans YAM 1 & $99 \cdot 4$ & 100 & & & & \\
\hline L. casei & $94 \cdot 7$ & $94 \cdot 3$ & 100 & & & \\
\hline L. paracasei & $94 \cdot 9$ & $94 \cdot 5$ & $99 \cdot 3$ & 100 & & \\
\hline L. rhamnosus & $94 \cdot 8$ & $94 \cdot 5$ & $98 \cdot 6$ & $98 \cdot 7$ & 100 & \\
\hline L. zeae & $95 \cdot 2$ & $94 \cdot 9$ & $99 \cdot 8$ & $99 \cdot 3$ & $99 \cdot 2$ & 100 \\
\hline
\end{tabular}

Table 3. Sequence signatures in the $16 \mathrm{~S}$ rDNAs of strains OND $32^{\top}$ and YAM 1 and of L. casei-related taxa

\begin{tabular}{|c|c|c|c|c|c|c|c|c|c|c|c|c|c|}
\hline \multirow[t]{2}{*}{ Strain } & \multicolumn{13}{|c|}{ Nucleotide at position:* } \\
\hline & 73 & 75 & 76 & 84 & 85 & 96 & 97 & 98 & 104 & 107 & 108 & 110 & 111 \\
\hline L. casei NCDO $161^{\mathrm{T}}$ & $\mathrm{T}$ & $\mathrm{G}$ & $\mathrm{G}$ & A & $\mathrm{C}$ & $\mathrm{C}$ & $\mathrm{T}$ & $G$ & $\mathrm{C}$ & $\mathrm{C}$ & $\mathrm{T}$ & $\mathrm{A}$ & A \\
\hline L. zeae ATCC $15820^{\mathrm{T}}$ & $\mathrm{T}$ & $\mathrm{G}$ & $\mathrm{G}$ & A & $\mathrm{C}$ & $\mathrm{T}$ & $\mathrm{C}$ & $\mathrm{G}$ & $\mathrm{C}$ & $\mathrm{C}$ & $\mathrm{T}$ & A & A \\
\hline L. paracase JCM $8130^{\mathrm{T}}$ & $\mathrm{C}$ & $\mathrm{C}$ & $\mathrm{G}$ & $\mathrm{T}$ & $\mathrm{C}$ & $\mathrm{C}$ & $\mathrm{C}$ & $\mathrm{G}$ & $\mathrm{C}$ & $\mathrm{C}$ & A & $\mathrm{G}$ & $\mathrm{G}$ \\
\hline L. rhamnosus DSM $20021^{\mathrm{T}}$ & $\mathrm{C}$ & $\mathrm{G}$ & $\mathrm{A}$ & A & A & $\mathrm{T}$ & $\mathrm{C}$ & $\mathrm{T}$ & $\mathrm{T}$ & $\mathrm{T}$ & $\mathrm{T}$ & $\mathrm{T}$ & $\mathrm{G}$ \\
\hline L. manihotivorans OND $32^{\mathrm{T}}$ & $\mathrm{T}$ & $\mathrm{T}$ & $\mathrm{A}$ & A & $-\dagger$ & $\mathrm{G}$ & $\mathrm{T}$ & A & $\mathrm{T}$ & $\mathrm{C}$ & $\mathrm{T}$ & A & A \\
\hline L. manihotivorans YAM 1 & $\mathrm{~T}$ & $\mathrm{~T}$ & $\mathrm{~A}$ & A & $-\dagger$ & $\mathrm{G}$ & $\mathrm{T}$ & A & $\mathrm{T}$ & $\mathrm{C}$ & $\mathrm{T}$ & A & A \\
\hline
\end{tabular}

* Nucleotide position from the 5' end of the 16S rDNA sequence of $L$. casei.

$\uparrow$ To achieve optimal alignment, no base was found in this position.

clearly belong to the genus Lactobacillus and are closely related to $L$. casei group, which contains the subspecies $L$. casei subsp. casei, L. casei subsp. tolerans, Lactobacillus rhamnosus and L. zeae (Dicks et al., 1996). The 16S rRNA sequences of strains OND $32^{\mathrm{T}}$, YAM 1 and four representative strains of the $L$. casei group, were aligned and a distance matrix was assembled (Table 2). The levels of sequence similarity between the $L$. casei strains are much higher $(98.6-99 \cdot 8 \%)$ than the level of similarity between the L. case $i$ strains and the OND $32^{\mathbf{T}}$ and YAM 1 strains $(94 \cdot 3-95 \cdot 2 \%)$. The most drastic structural difference occurred at positions 66-103 (E. coli numbering system).

To differentiate the four $L$. casei-related taxa, Mori et al. (1997) have defined sequence signatures in the $16 \mathrm{~S}$ rRNAs sequences at positions 66-103 (E. coli numbering system) that differed from the sequences at the same positions in OND $32^{\mathrm{T}}$ and YAM 1 16S rRNA sequences (Table 3). However, OND $32^{\mathrm{T}}$ and YAM 1 share the same sequence signature in this region. This shows that both strains OND $32^{\mathrm{T}}$ and YAM 1 are more closely related to each other than they are to $L$. casei. A minor structural difference between $L$. casei

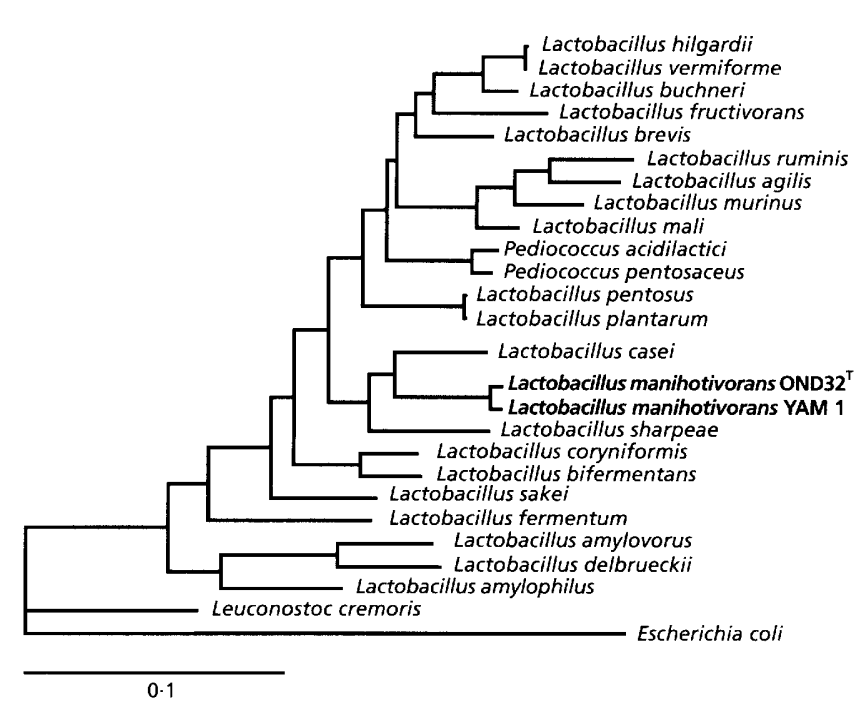

Fig. 2. Phylogenetic dendrogram derived from 165 rDNA sequence analysis showing the relationships of strains OND $32^{\top}$ and YAM 1 to other lactic acid bacteria and $E$. coli. The dendrogram was generated by applying a maximum-likelihood approach of bootstrapped data sets. Scale bar, $10 \%$ estimated sequence divergence. 


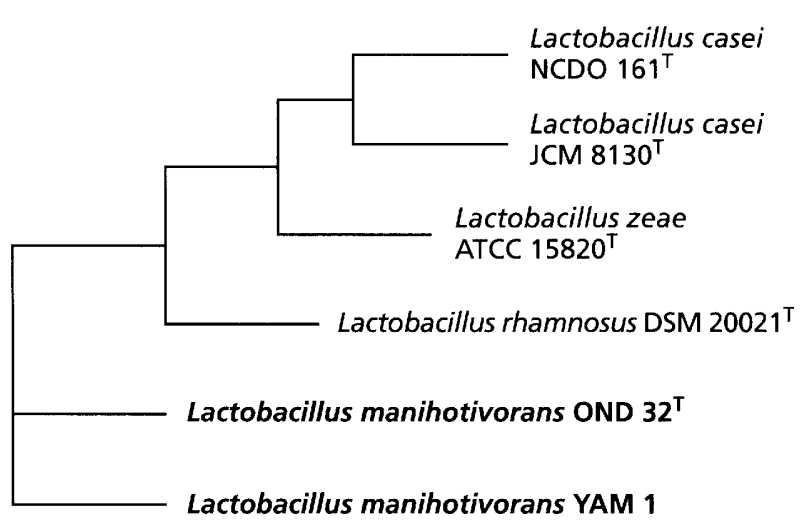

Fig. 3. Unrooted tree derived from 165 rDNA sequence analysis and showing the phylogenetic relationships of strains OND $32^{\top}$ and YAM 1 and $L$. casei-related taxa. The dendrogram was generated by applying a maximum-likelihood approach of bootstrapped data sets. Scale bar, $10 \%$ nucleotide substitution.

and strains OND $32^{\mathrm{T}}$ and YAM 1 was also found in regions susceptible to stem-loop formation [positions 199-226 and 286-296 (E. coli numbering system)].

Alternative tree-making programs available in the PHYLIP package (Felsenstein, 1993) produced trees that were topologically similar to the tree shown in Fig. 2. This dendrogram (Fig. 2) shows the phylogenetic position of OND $32^{\mathrm{T}}$ and YAM 1 compared to the L. casei/Pediococcus cluster, as well as to other reference species scattered outside this cluster. Treeing analysis confirmed that OND $32^{\mathrm{T}}$ and YAM 1 are closely related to members of $L$. casei/Pediococcus cluster. The dendrogram in Fig. 3 shows a detailed position of OND $32^{\mathrm{T}}$ and YAM 1 within the L. casei cluster and strongly suggests that OND $32^{\mathrm{T}}$ and YAM 1 form a distinct group within the cluster.

\section{DISCUSSION}

Strains OND $32^{\mathrm{T}}$ and YAM 1, isolated from a traditional Colombian cassava fermentation process and used to produce sour starch, are Gram-positive, non-spore-forming, mesophilic, homolactic, facultatively anaerobic bacteria. Like lactic acid bacteria, they are non-spore-forming, chemo-organotrophic and catalase-negative. The type of metabolism and low DNA G + C content $(48 \cdot 4 \pm 0 \cdot 2 \mathrm{~mol} \%)$ of strains OND $32^{\mathrm{T}}$ and YAM 1, together with their morphological and physiological characteristics, are consistent with the description of the genus Lactobacillus (Dellaglio et al., 1994; Hammes \& Vogel, 1995).

Since strains OND $32^{\mathrm{T}}$ and YAM 1 produce only lactic acid and do not ferment pentose or gluconate they should be considered to be obligately homofermentative and should be included in lactobacilli Group I as proposed by Kandler \& Weiss (1986) or classified either in phylogenetic Cluster 1 (the Lactobacillus delbrueckii group, which contains obligately homofermentative species) or in Cluster 2 (the L. casei/
Pediococcus group, which contains a limited number of obligately homofermentative as well as a majority of heterofermentative species) (Collins et al., 1991). For the sake of simplicity, the term Group I lactobacilli is used in this report to cover both the obligately homofermentative lactobacilli described by Kandler \& Weiss (1986), and the obligately homofermentative species of Cluster 2 of Collins et al. (1991).

Differential characteristics of strains OND $32^{\mathrm{T}}$ and YAM 1 with obligately homofermentative Lactobacillus species are shown in Table 4. Among starch degraders which belong to Group I, the ability of OND $32^{\mathrm{T}}$ and YAM 1 to produce $\mathrm{L}(+)$ lactic acid only is a characteristic which differentiates them from $L$. amylovorus (DL-lactic acid producer). Unlike strains OND $32^{\mathrm{T}}$ and YAM 1, L. amylovorus is also unable to ferment lactose, melibiose, raffinose and does not grow at $15^{\circ} \mathrm{C}$ (Hammes \& Vogel, 1995). When compared to L. amylophilus [Group I, L $(+)$ lactic acid producer], strains OND $32^{\mathrm{T}}$ and YAM 1 differ in the use of cellobiose, lactose, melibiose, raffinose, sucrose, amygdalin and aesculin. Based on these criteria, strains OND $32^{\mathrm{T}}$ and YAM 1 are clearly different from previously described ALAB of Group I.

Characteristics of strains OND $32^{\mathrm{T}}$ and YAM 1 which differentiate them from non-amylolytic species belonging to Group I are listed in Table 4, and encompass the fermentation of amygdalin, melibiose, raffinose, trehalose, cellobiose and sorbitol, lactic acid isomer, growth at $15^{\circ} \mathrm{C}$, and $\mathrm{G}+\mathrm{C}$ content. Among the $\mathrm{L}(+)$ lactic acid producers of Group I, Lactobacillus animalis and Lactobacillus ruminis closely resemble strains OND $32^{\mathrm{T}}$ and YAM 1 (Table 4), but both species do not use trehalose and do not grow at $15^{\circ} \mathrm{C}$. Strains OND $32^{\mathrm{T}}$ and YAM 1 are similar to species belonging to the $L$. delbrueckii group (Hammes \& Vogel, 1995), such as Lactobacillus johnsonii and Lactobacillus gallinarum (Table 4) but differ from $L$. johnsonii in that they use melibiose and from $L$. gallinarum in that they use of trehalose and have a very different $\mathrm{G}+\mathrm{C}$ content. Strains OND $32^{\mathrm{T}}$ and YAM 1 differ from Lactobacillus mali by their $\mathrm{G}+\mathrm{C}$ content.

Based on the analysis of protein electrophoretic patterns, a first group of reference strains consisted of 20 strains belonging to the $L$. casei group comprising Lactobacillus (para)casei, L. rhamnosus and L. zeae. As expected, the L. casei cluster (Dicks et al., 1996) contains the type strain of Lactobacillus paracasei (Collins et al., 1989). The three species can clearly be discriminated. The type strain of $L$. casei subsp. tolerans occupies a separate position in the $L$. casei cluster with a correlation value of $73.9 \%$. The remaining members of this cluster show homologies above $88 \%$.

A second group of reference strains consisted of 28 reference strains of the Lactobacillus acidophilus complex belonging to the L. delbrueckii group (Hammes \& Vogel, 1995). Representative strains of seven species (L. gallinarum, L. amylovorus, Lactobacillus helveticus, 
Table 4. Main differential characteristics between strains OND $32^{\top}$ and YAM 1 and closely related obligately homofermentative Lactobacillus spp. (Group I)

,$+ 90 \%$ or more strains positive;,$- 90 \%$ or more strains negative; $\mathrm{d}, 11-89 \%$ strains positive; ND, not done; $+_{w}$, positive to weak reaction.

\begin{tabular}{|c|c|c|c|c|c|c|c|c|}
\hline \multirow[t]{2}{*}{ Lactobacillus species (mol $\% \mathrm{G}+\mathrm{C}$ ) } & \multicolumn{6}{|c|}{ Acid production from: } & \multirow[t]{2}{*}{ Lactic acid isomers* } & \multirow[t]{2}{*}{ Growth at $15^{\circ} \mathrm{C}$} \\
\hline & Starch & Amygdalin & Cellobiose & Melibiose & Raffinose & Trehalose & & \\
\hline OND $32^{\mathrm{r}}$ and YAM $1(48 \cdot 4)$ & + & + & + & + & + & + & $\mathbf{L}$ & + \\
\hline L. acidophitust (34-37) & d & + & + & $\mathrm{d}$ & $d$ & $\mathrm{~d}$ & DL & - \\
\hline L. kefirgramim ${ }_{+}^{+}(34 \cdot 3-38 \cdot 6)$ & ND & - & $\mathrm{d}$ & + & + & d & $\mathrm{D}(\mathrm{L})$ & $t_{w}$ \\
\hline L. kefiramofarithlst. \$ (34-35) & ND & - & - & + & + & - & $D(L)$ & - \\
\hline L. johnsomiit+. $\$\left(\begin{array}{l}35 \\
\text { 3 } 38)\end{array}\right.$ & ND) & + & + & - & d & $\mathrm{d}$ & L $\ddagger$ & + \\
\hline L. gallinarum $+\$(36-37)$ & $d$ & + & + & + & + & - & $\mathrm{L} \ddagger$ & + \\
\hline L. amytophiliws (44 46) & + & - & - & - & - & - & $\mathbf{L}$ & + \\
\hline L. amyloroms $(40-41)$ & + & $+_{w}$ & + & - & - & + & $\mathrm{DL}$. & - \\
\hline L. animalis (41 44) & ND & d & + & + & + & - & $\mathrm{L}$ & - \\
\hline L. crispatws $(35-38)$ & d & + & + & - & - & - & $\mathrm{DL}$ & - \\
\hline L. farciminis $(34+36)$ & - & + & + & - & - & + & I.(D) & + \\
\hline L. gasseri $(3,35)$ & d & + & + & $\mathrm{d}$ & $\mathrm{d}$ & d & DL & - \\
\hline L. helveticus $(38-40)$ & - & - & - & - & - & $d$ & DL & - \\
\hline L. jensenii (35-.37) & - & + & + & - & - & + & $\mathrm{D}$ & - \\
\hline L. rumints $(44$ 47) & & + & + & + & + & - & L & - \\
\hline L. salivarius (34-36) & - & - & - & + & + & + & $\mathrm{L}$ & - \\
\hline L. sharpeae $(53)$ & ND & + & + & - & - & - & $\mathrm{L}$ & + \\
\hline L. vitulims ( 44 37) & ND & + & + & + & + & $\mathrm{d}$ & $\mathrm{D}$ & - \\
\hline L. malis (L. amanashiensis $\dagger)(32-34)$ & ND & + & + & d & $\mathrm{d}$ & + & $\mathrm{L}$ or $\mathrm{DL}$ & + \\
\hline
\end{tabular}

* Based on the content of $\mathrm{L}(+)$ lactic acid: D, 0-20\%; L, 80-100\%; L(D), the D isomer makes up 15-20\% total lactic acid (data from Kandler \& Weiss, 1986); $\mathrm{D}(\mathrm{L})$, the $\mathrm{L}$ isomer makes up 20-40\% total lactic acid (data from Takizawa et al., 1994).

$\dagger$ Data from Kandler \& Weiss (1986).

$\$$ Data from Takizawa et al. (1994).

$\S$ Data from Dellaglio et al. (1994).

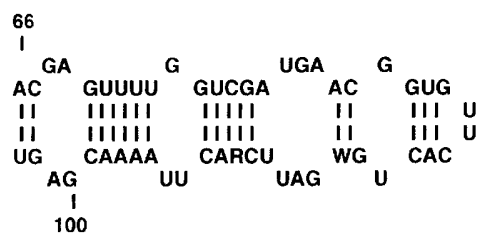

Lactobacillus casei NCDO $161^{\top}$

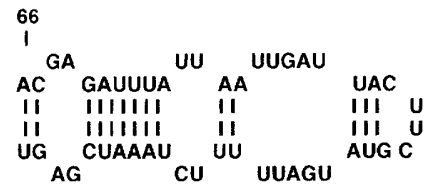

Lactobacillus manihotivorans OND $32^{\top}$

Fig. 4. Secondary structures of a $16 \mathrm{~S}$ rRNA region (positions 66-103 of the $E$. coli numbering system) of strain OND $32^{\top}$ and Lactobacillus casei.

L. acidophilus, L. johnsonii, Lactobacillus gasseri and Lactobacillus crispatus, Fig. 1) form separate clusters with correlation values between 94.7 (L. amylovorus) and $89.4 \%$ (L. johnsonii). The relationship between these species and L. manihotivorans is less than $57 \%$ (Fig. 1).

To determine the evolutionary and taxonomic position of OND $32^{\mathrm{T}}$ and YAM 1, the sequences of their $16 \mathrm{~S}$
rDNAs were compared. This appears to be one of the most appropriate methods for determining taxonomic relationships (Fox et al., 1980; Woese, 1987). Several types of distance matrix and tree-generating programs (Felsenstein, 1993) were used to analyse the sequence data. All the results obtained showed that OND $32^{\mathrm{T}}$ and YAM 1 belong to the same species and that they form a distinct cluster.

This phylogenetic analysis of $16 \mathrm{~S}$ rRNA sequences was consistent with the DNA G $+\mathrm{C}$ content of strain OND $32^{\mathrm{T}}(48.4 \mathrm{~mol} \%)$, situating the strain between L. casei $(46 \mathrm{~mol} \%)$ and Lactobacillus sharpeae $(53 \mathrm{~mol} \%)$. The patterns of variation in the secondary structure of the hypervariable region of the $16 \mathrm{~S} r \mathrm{RNAs}$ (positions 66-103 of the $E$. coli numbering system; Fig. 4) also support the hypothesis that OND $32^{\mathrm{T}}$ and YAM 1 should be differentiated and separated from other members of the $L$. casei group.

In view of the presented phylogenetic evidence (16S rRNA), protein pattern differences measured by SDSPAGE and the phenotypic distinctiveness of OND $32^{\mathrm{T}}$ and YAM 1, it is proposed that these strains belong to a new species Lactobacillus manihotivorans sp. nov.

\section{Description of Lactobacillus manihotivorans sp. nov.}

Lactobacillus manihotivorans (ma.ni.ho.ti.vo'rans. L. n. manihot cassava; L. v. vorare to devour; M.L. adj. manihotivorans cassava-devouring). 
Cells are Gram-positive, non-motile, non-spore-forming rods which occur in short chains or occasionally as single cells. Grows at 15 and $45^{\circ} \mathrm{C}$. Optimal temperature and $\mathrm{pH}$ for growth are about $30^{\circ} \mathrm{C}$ and $6 \cdot 0$, respectively. Grows at $\mathrm{NaCl}$ concentrations of $20-65 \mathrm{~g}$ $\mathrm{l}^{-1}$ and does not grow at $100 \mathrm{~g} \mathrm{l}^{-1} \mathrm{NaCl}$. Facultatively anaerobic. Catalase-negative. Obligately homofermentative, produces $L(+)$ lactic acid. Starch is utilized. Strain OND $32^{\mathrm{T}}$ has an extracellular amylase activity and strain YAM 1 shows cell-linked amylase activity. Acid is produced from cellobiose, mannose, sucrose, lactose, raffinose, trehalose, aesculin, salicin, amygdalin, methyl $\alpha$-D-glucoside, $\beta$-gentobiose and $N$ acetylglucosamine. Pentoses are not used. The DNA $\mathrm{G}+\mathrm{C}$ content of the type strain is $48 \cdot 4 \pm 0 \cdot 2 \%$. The type strain is strain OND $32^{\mathrm{T}}\left(=\mathrm{LMG} 18010^{\mathrm{T}}\right)$.

\section{ACKNOWLEDGEMENTS}

We are indebted to Dr J. L. Garcia for his Latin proficiency and for his help in naming Lactobacillus manihotivorans. We thank J. L. Cayol for helpful discussions.

This work is part of a collaborative research project between ORSTOM and CIRAD partially supported by the Commission of European Communities (contract TS3-CT92$0110)$.

B.P. is indebted to the Belgian Prime Ministers Services, Federal Office for Scientific, Technical and Cultural Affairs for financing of the Belgian Coordinated Collections of Microorganisms (BCCM/LMG).

\section{REFERENCES}

Balch, W. E., Fox, G. E., Magrum, L. J., Woese, C. R. \& Wolfe, R. S. (1979). Methanogens: re-evaluation of a unique biological group. Microb Rev 43, 260-296.

Champ, M., Szylit, O., Raibaud, P. \& Abdelkader, A. (1983). Amylase production by three Lactobacillus strains isolated from chicken crop. J Appl Bacteriol 55, 487-493.

Chuzel, G., Zakhia, N. \& Cereda, M. P. (1995). Potentialités de nouveaux produits dérivés du manioc au Brésil. In Transformations Alimentaires du Manioc, pp. 571-579. Edited by T. A. Egbe, A. Brauman, D. Griffon \& S. Trèche. Paris: ORSTOM.

Collins, M. D., Phillips, B. A. \& Zanoni, P. (1989). Deoxyribonucleic acid homology studies of Lactobacillus casei, Lactobacillus paracasei sp. nov., subsp. paracasei and subsp. tolerans, and Lactobacillus rhamnosus sp. nov., comb. nov. Int $J$ Syst Bacteriol 39, 105-108.

Collins, M. D., Rodriguez, U., Ash, C., Aguirre, M., Farrow, J. A. E., Martinez-Murcia, A., Philips, B. A., Williams, A. M. \& Walbanks, S. (1991). Phylogenetic analysis of the genus Lactobacillus and related lactic acid bacteria as determined by reverse transcriptase sequencing of $16 \mathrm{~S}$ rRNA. FEMS Microbiol Lett 77, 5-12.

Combet-Blanc, Y., Ollivier, B., Streicher, C., Patel, B. K., Dwivedi, P. P., Pot, B., Prensier, G. \& Garcia, J. L. (1995). Bacillus thermoamylovorans sp. nov., a moderately thermophilic and amylolytic bacterium. Int J Syst Bacteriol 45, 9-16.

Damelin, L. H., Dykes, G. A. \& von Holy, A. (1995). Biodiversity of lactic acid bacteria from food-related ecosystems. Microbios $\mathbf{8 3}$, $13-22$.
Dellaglio, F., de Roissart, H., Torriani, S., Curk, M. C. \& Janssens, D. (1994). Caractéristiques générales des bactéries lactiques. In Bactéries Lactiques: Aspects Fondamentaux et Technologiques, pp. 25-116. Edited by H. de Roissart \& F. M. Luquet. Uriage, France: Lorica.

De Man, J. C., Rogosa, M. \& Sharpe, M. E. (1960). A medium for the cultivation of lactobacilli. $J$ App/ Bacteriol 23, 130-135.

Devereux, J., Haeberli, P. \& Smithies, O. (1984). A comprehensive set of sequence analysis programs for the VAX. Nucleic Acids Res 12, 387-395.

Dicks, L. M. T., Du Plessis, E. M., Dellaglio, F. \& Lauer, E. (1996). Reclassification of Lactobacillus casei subsp. casei ATCC 393 and Lactobacillus rhamnosus ATCC 15820 as Lactobacillus zeae nom. rev., designation of ATCC 334 as the neotype of L. case $i$ subsp. casei and rejection of the name Lactobacillus paracasei. Int J Syst Bacteriol 46, 337-340.

Dufour, D., Brabet, C., Zakhia, N. \& Chuzel, G. (1995). Influence de la fermentation et du séchage solaire sur l'acquisition du pouvoir de panification de l'amidon aîgre de manioc. In Transformations Alimentaires du Manioc, pp. 399-416. Edited by T. A. Egbe, A. Brauman, D. Griffon \& S. Trèche. Paris: ORSTOM.

Felsenstein, J. (1993). PHYLIP (phylogenetic inference package), version $3.5 \mathrm{lc}$. Department of Genetics, University of Washington, Seattle, WA, USA.

Fox, G. E., Stackebrandt, E., Hespelle, R. B. \& 15 other authors (1980). The phylogeny of procaryotes. Science 209, 457-463.

Giraud, E., Brauman, A., Keleke, S., Lelong, B. \& Raimbault, M. (1991). Isolation and physiological study of an amylolytic strain of Lactobacillus plantarum. Appl Microbiol Biotechnol 36. 379-383.

Giraud, E., Champailler, A. \& Raimbault, M. (1994). Degradation of raw starch by a wild amylolytic strain of Lactobacillus plantarum. Appl Microbiol 60, 43194323.

Gregersen, T. (1978). Rapid method for distinction of Gramnegative from Gram-positive bacteria. Eur J Appl Microbiol Biotechnol 5, 123-127.

Hammes, W. P. \& Vogel, R. F. (1995). The genus Lactobacillus. In The Lactic Acid Bacteria, vol. 2, The Genera of Lactic Acid Bacteria, pp. 19-54. Edited by B. J. B. Wood \& W. H. Holzapfel. Glasgow: Chapman \& Hall.

Jukes, T. H. \& Cantor, C. R. (1969). Evolution of protein molecules. In Mammalian Protein Metabolism, pp. 21-132. Edited by H. N. Munro. New York: Academic Press.

Kandler, O. \& Weiss, N. (1986). Genus Lactobacillus Beijerinck 1901, 212 ${ }^{\mathrm{A}}$. In Bergey's Manual of Systematic Bacteriology, vol. 2, pp. 1209-1234. Edited by P. H. A. Sneath, N. S. Mair, M. E. Sharpe \& J. G. Holt. Baltimore: Williams \& Wilkins.

Koch, A. (1981). Growth measurement. In Manual of Methods for General Bacteriology, pp. 192-197. Edited by P. Gerdardt, R. G. E. Murray, R. N. Costilow, E. W. Nester, W. A. Wood, N. R. Krieg \& G. B. Phillips. Washington, DC: American Society for Microbiology.

Lane, D. J. (1991). 16S/23S rRNA sequencing. In Nucleic Acid Techniques in Bacterial Systematics, pp. 115-175. Edited by E. Stackebrandt \& M. Goodfellow. Chichester: Wiley.

Lindgren, S. \& Refai, O. (1984). Amylolytic lactic acid bacteria in fish silage. $J$ Appl Bacteriol 57, 221-228.

McClelland, M., Jones, R., Patel, Y. \& Nelson, M. (1987). Restriction endonucleases for pulsed field mapping of bacterial genomes. Nucleic Acids Res 15, 5985-6005. 
Maidak, B. L., Olsen, G. J., Larsen, N., Overbeek, R., McCaughey, M. J. \& Woese, C. R. (1996). The Ribosomal Database Project (RDP). Nucleic Acids Res 24, 82-85.

Mercier, P., Yerushalmi, L., Rouleau, D. \& Dochain, D. (1992). Kinetics of lactic acid fermentation on glucose and corn by Lactobacillus amylophilus. J Chem Technol Biotechnol 55, 111-121.

Meshbah, M., Premachandran, U. \& Whitman, W. B. (1989) Precise meatsurement of the $\mathrm{G}+\mathrm{C}$ content of deoxyribonucleic acid by high-performance liquid chromatography. Int $J$ Syst Bacteriol 39. 159-167.

Mori, K., Yamazaki, K., Ishiyama, T., Katsumata, M., Kobayashi, K., Kawai, Y., Inoue, N. \& Shinano, H. (1997). Comparative sequence analyses of the genes coding for 16S rRNA of Lactobacillus casei-related taxa. Int J Syst Bacteriol 47, 54-57.

Nakamura, L. K. (1981). Lactobacillus amylovorus, a new starchhydrolyzing species from cattle waste-corn fermentations. Int $J$ Syst Bacteriol 31, 56-63.

Nakamura, L. K. \& Crowell, C. D. (1979). Lactobacillus amylophilus, a new starch-hydrolyzing species from swine waste-corn fermentation. Dev Ind Microbiol 20, 531-540.

Neef, J. M., Van de Peer, Y., Hendriks, L. \& de Wachter, R. (1990). Comparison of small ribosomal subunit RNA sequences. Nucleic Acids Res 18 (suppl.), 2237-2319.

Olympia, M., Fukuda, H., Ono, H., Kaneko, Y. \& Takan, M. (1995). Characterization of starch-hydrolyzing lactic acid bacteria from a fermented fish and rice food, 'burong isda', and its amylolytic enzyme. J Ferment Bioeng 80, 124-130.

Pearson, W. R. \& Lipman, D. J. (1988). Improved tools for biological sequence comparison. Proc Natl Acad Sci USA 85, 2444-2448.

Pompeyo, C. C., Gómez, M. S., Gasparian, S. \& Morlon-Guyot, J. (1993). Comparison of amylolytic properties of Lactobacillus amylovorus and of Lactobacillus amylophilus. Appl Microbiol Biotechnol 40, 266-269.

Pot, B. \& Janssens, D. (1993). The potential role of a culture collection for identification and maintenance of lactic acid bacteria. In The Lactic Acid Bacteria, pp. 81-87. Edited by
E. L. Foo, H. G. Griffin, R. Möllby \& C. G. Hedén. Norfolk: Horizon Scientific Press.

Pot, B., Hertel, C., Ludwig, W., Descheemaeker, P., Kersters, K. \& Schleifer, K. H. (1993). Identification and classification of Lactobacillus acidophilus, L. gasseri and L. johnsonii strains by SDSPAGE and rRNA-targeted oligonucleotide probe hybridization. $J$ Gen Microbiol 139, 513-517.

Pot, B., Vandamme, P. \& Kesters, K. (1994a). Analysis of electrophoretic whole organism protein fingerprints. In Chemical Methods in Prokaryotic Systematics, p. 493. Edited by M. Goodfellow \& A. G. O'Donnell. Chichester: Wiley.

Pot, B., Devriese, L. A., Hommez, J., Miry, C., Vandemeulebroecke, K., Kersters, K. \& Haesebrouck, F. (1994b). Characterization and identification of Vagococcus fluvialis strains isolated from domestic animals. $J$ Appl Bacteriol 77, 362-369.

Sanger, F., Nicklen, S. \& Coulson, A. R. (1977). DNA sequencing with chain-terminating inhibitors. Proc Natl Acad Sci USA 74, 5463-5467.

Takizawa, S., Kojima, S., Tamura, S., Fujinaga, S., Benno, Y. \& Nakase, T. (1994). Lactobacillus kefirgranum sp. nov. and Lactobacillus parakefir sp. nov., two new species from kefir grains. Int J Syst Bacteriol 44, 435-439.

Thomson, J. D., Higgins, D. G. \& Gibson, T. J. (1994). CLUSTAL W: improving the sensitivity of progressive multiple sequence alignment through sequence weighting, position-specific, gap penalties and weight matrix choice. Nucleic Acids Res 22, 4673-4680.

Vauterin, L. \& Vauterin, P. (1992). Computer-aided objective comparison of electrophoresis patterns for grouping and identification of microorganisms. Eur J Microbiol 1, 37-41.

Woese, C. R. (1987). Bacterial evolution. Microbiol Rev 51, 221-271.

Yumoto, I. \& Ikeda, K. (1995). Direct fermentation of starch to $\mathrm{L}(+)$ lactic acid using Lactobacillus amylophilus. Biotechnol Lett 17, 543-546.

Zhang, D. X. \& Cheyran, M. (1991). Direct fermentation of starch to lactic acid by Lactobacillus amylovorus. Biotechnol Lett $\mathbf{1 3}$, $733-738$ 
